\title{
The waste remover in aquaculture ponds
}

\author{
Le The Truyen ${ }^{1, *}$, Le Thanh Long ${ }^{2}$
}

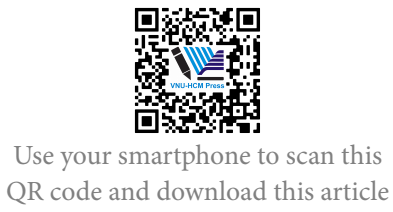

${ }^{1}$ Key Laboratory of Digital Control and System Engineering, HCMUT (DCSELAB), VNU-HCM, Vietnam.

${ }^{2}$ Faculty of Mechanical Engineering, Ho Chi Minh University of Technology, VNU-HCM, Vietnam.

Correspondence

Le The Truyen, Key Laboratory of Digital Control and System Engineering, HCMUT (DCSELAB), VNU-HCM, Vietnam.

Email: truyenlt@hcmut.edu.vn

History

- Received: 15/10/2018

- Accepted: 15/12/2018

- Published: 31/12/2019

DOI : 10.32508/stdjet.v3iSI1.729

\section{Check for updates}

\section{Copyright}

(c) VNU-HCM Press. This is an openaccess article distributed under the terms of the Creative Commons Attribution 4.0 International license.

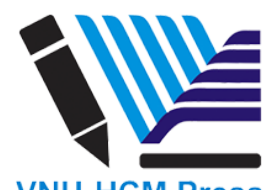

\begin{abstract}
Over the past decade, Vietnam's shrimp industry has made great progress and brings Vietnam into the rank of the world's largest shrimp exporters. The development trend of the shrimp industry in the world as well as in Vietnam today is in the direction of intensive and super-intensive farming, technology innovation to enhance productivity and quality. However, the shrimp farming industry in Vietnam is facing many difficulties; one of them is the problem of environmental pollution, raising negative impact on the economic effectiveness of farming. Causes are mainly due to excess food and untreated shrimp waste, accumulated on the pond bottom surface and disintegrated to reduce dissolved oxygen concentration, release toxic gases such as $\mathrm{NH}_{3}, \mathrm{H}_{2} \mathrm{~S}$ and create a favorable environment for harmful microorganisms to develop. Therefore, it is necessary to have a countermeasure to thoroughly remove waste from the farming environment. This paper introduces a general design of a waste remover, which is needed for shrimp farming ponds to remove waste and solve the mentioned problem. This equipment moves on the bottom surface of the pond and can be autonomous or manually remote controlled. During working process, the equipment brushes waste on the bottom surface of the pond and suck it into the filter bag. The waste remover includes such following main units: travelling unit, brushing unit, sucking unit, frame unit, transmission and control systems. The equipment uses the principle of axial pumping, sucks waste along the water stream by reducing the pressure inside the equipment and transfers waste into filter bags. This general design basically meets the requirement of waste removal and can be a fundamental for designing the detailed units, manufacturing and experiment implementation of equipment in the future.
\end{abstract}

Key words: Aquaculture ponds, Brush cluster, Pump cluster, Waste remover

\section{INTRODUCTION}

The shrimp pond liner model $35 \times 35 \mathrm{~m}$ with siphon pit, the paddle wheel systems is the main obstacle that the equipment must surpass. Surface pond bottom is not flat and waste is often deposited at the bottom of the rough point. A study pointed out that the attribution waste in the pond has the paddle wheel systems, the waste centralizes primarily in the middle area of the pond and surrounds siphon pit ${ }^{1}$. Most of the waste is collected in the siphon pit, but the rest need to be removed from the pond. Significant sludge buildup may negatively affect the target crop by increasing biological oxygen demand, reducing usable habitat, decreasing availability of natural prey organisms and releasing toxic compounds ${ }^{2}$. Typically, effluents from aquaculture are characterized by increased nitrogen species (ammonia, nitrites, and nitrates), organic carbon, phosphates, suspended solids, and high biological oxygen demand (BOD) and chemical oxygen demand $(\mathrm{COD})^{3}$. Significant issues can result in the release of nutrient rich effluents such as these including increased algal blooms, degradation of benthic communities, oxygen depletion, and overall degraded water quality ${ }^{4}$. Successful shrimp aquaculture requires maintenance of water quality conducive for the growth of shrimp. Common water quality concerns for shrimp aquaculture include inorganic suspended solids (ISS), total suspended solids (TSS), biochemical oxygen demand (BOD), chemical oxygen demand (COD), dissolved oxygen (DO), and nitrogen ${ }^{5,6}$. A number of physical, chemical and biological methods used in conventional wastewater treatment has been applied in aquaculture systems. These methods are suitable for tank or small ponds ${ }^{7}$. Mechanical method of sludge removal may be the solution for commercial intensive aquaculture. In Vietnam, farmers are using sludge pump for removing sludge from fish pond to create healthy environment in the fish pond ${ }^{8}$. A sludge remover was designed and fabricated at Farm Machinery and Postharvest Process Engineering (FMPE) Division of Bangladesh Agricultural Research Institute (BARI), Gazipur, Bangladesh with locally available materials. The main functional components of the remover were axial flow pump, engine, suction pipe, sludge collector with cutter, delivery pipe, float, propeller, rudder, crane, etc ${ }^{9}$. 
In Viet Nam, the study aims at designing of equipment to clean shrimp pond bottom to replace the manual cleaning is not interested in research investment, shrimp farmers have to wade in ponds daily using hand tools to clean the bottom of the pond. This paper introduces a general design of a waste remover, which is needed for shrimp farming ponds to remove waste and solve the mentioned problem.

\section{MATERIALS AND METHODS}

\section{Cluster moving and transmission system for cluster moving}

The equipment is determined to move on the bottom of the pond so the options using the wheels are selected with two wheels (Figure 1a), three wheels (Figure 1b) and four wheels (Figure 1c). However, with working conditions under water environment, the friction of the wheel with the bottom of the pond is reduced, so that the contact surface between the wheel and the bottom surface of the pond must be large to increase the friction between the equipment and the bottom pond. The method using belt was selected for increase the friction, the wheel should be converted into the pulley and move through the friction between belt surface and bottom surface of the pond. The option using three pulleys are eliminated because it is difficult to arrange the belt. The bottom surface of the pond is not flat, so the option using four pulleys is selected instead of two pulleys to ensure balance while moving and turn right, turn left, and turn back of the equipment. The remaining problem is transmitted torque for the pulley, two proposed methods is using the differential gear with one motor or using two independent control servomotors and direct transmits. The differential gear can solve the problem of turn left, turn right and turning back but it is limited when the equipment moves off compare to trajectory because the bottom surface of the pond is not flat. As a result, two independent control servomotors are selected, which enables the equipment to be more flexible and easier to adjust as the equipment moves off trajectory.

\section{Pump cluster}

The main task of the equipment is to suck waste deposited on the bottom of the pond and remove it from the culture pond. To perform this function, the equipment is equipped with a filter capable of filtering and holding the waste. Waste is sucked into the filter bag according to water flow, so the filter bag should be attached to a pipe suck.
To increase the working time, the equipment requires a large filter bag, so the filter is designed with two pipes suck and two filter bags arranged on either side, the suction mouth is arranged at the bottom of the equipment to suck the waste on the surface of the pond bottom. In order to bring water and waste into the filter bag, it is necessary to select the appropriate type of pump. The waste and water can be suck into the filter bag, but this method must use two pumps. The simpler choice is to use atmospheric pressure to put the water in the filter bag, so the filter bag is placed in the body cavity of the equipment. The axial pump sucked water out of the body cavity through the outlet on the lid of the body. The pressure in body cavity decreased, the atmospheric pressure pushes the flow of water and waste in the body cavity in order to balance the pressure. As such, filter bags and suction pipes are designed to be assembled together by quick couplers for easy cleaning. At the quick couplers need one-way rubber valve to prevent the waste reflux back when the pump stopped working.

\section{Brush cluster and transmission system for cluster brush}

There are two methods to brush the surface of the proposed pond bottom lining, the vertical brush shaft (Figure 2a) and the horizontal brush shaft (Figure 2b). Regarding the vertical brushing shaft method, the brushing system will consist of two shafts that are rotated in opposite directions by a transmission belt, brushing and pushing water and waste into equipment chassis. However, this option cause hinders when the equipment overcome obstacles, and the transmission for vertical brushing shaft is more difficult than the horizontal brushing shaft. With horizontal brushing shaft system, the shaft is covered with soft and long enough bristles and is transmitted from the pulley shaft through the gear transmission. Due to the lager transmission, the brushing shaft rotates with large speed to ensure the ability of cleanliness. The waste is also pushed in equipment chassis for suction. The horizontal brushing shafts also supports for the equipment when it overcomes obstacles which are not too large at the bottom of the pond.

\section{Frame cluster}

The frame consists of two main parts, the lower half and the upper half of the frame are structured as a closed box. Internal space contains motors, pumps and filters. The lower half of the body is placed with 


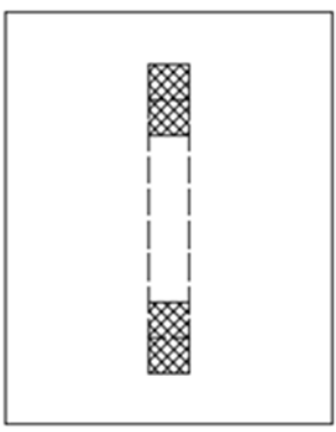

(a) Two wheels.

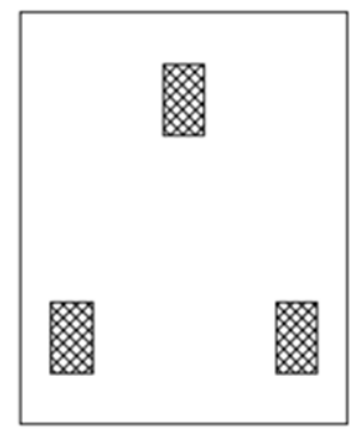

(b) Three wheels.

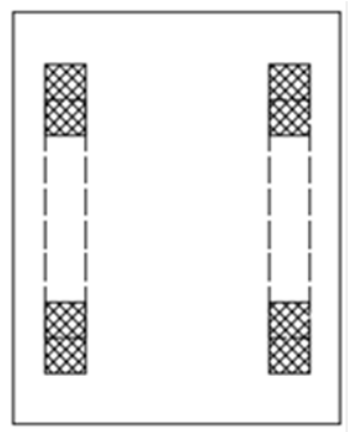

(c) Four wheels.

Figure 1: Methods using wheels.

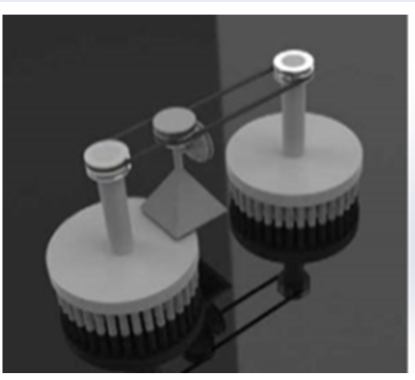

(a) The vertical brush shaft.

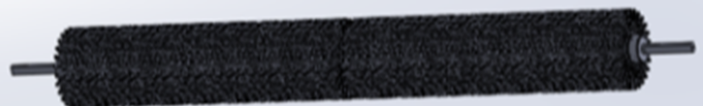

(d) The horizontal brush shaft.

Figure 2: Design methods brush shaft.

the suction gate, one-way drain valve to drain water out of the body cavity when the device stopped working. The upper haft of the body is designed to be assembled to the exhaust pipe of the pump and has two doors to disassemble the filter bag. The two halves form a closed cavity to limit the pressure loss in the cavity when the device is operating.

\section{The navigation and sensor system}

Self-propelled equipment at the bottom of the pond which needs to be monitoring the location of equipment, GPS navigation system is proposed. The first problem to be solved is the transmission of the signal when the equipment is moving under water and mitigates the deviation of the GPS navigation system. In order to solve the problem of signal transmission, the GPS sensor is assembled on the float and floating on the water, the float holding mechanism is rigid enough so that the float is not drifted, cause of the deviation between the float and the equipment. However, the deviation of the GPS is still very significant.
The second solution is replaced the GPS with ultrasonic beacon sets, a mobile beacon equipment assembled on the waste remover and four fixed beacons are placed at the four corners of the pond. The position of the equipment is determined by the four fixed beacons via an algorithm. In addition, the equipment is equipped with rotary angle and acceleration sensor to adjust when the equipment moves off trajectory. For monitoring location of equipment, four fixed beacons create a pond map, software used to connect the navigation system to draw the operating trajectory for the equipment, so that it can monitor and control the operation of equipment on the computer screen.

Based on the initial analysis, the schematic diagram and the general diagram of the equipment's control system are defined.

The schematic diagram (Figure 3) illustrates the arrangement of main components and the motions when the equipment is operating. 


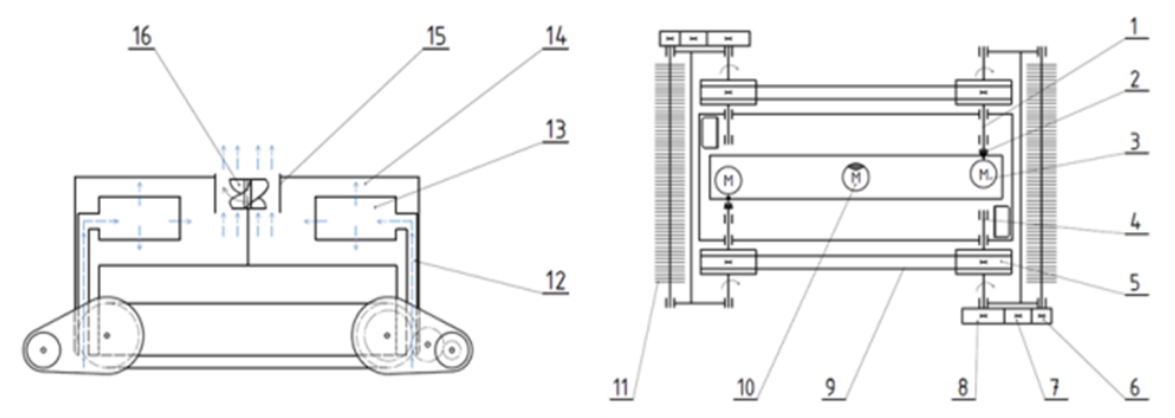

Figure 3: The schematic diagram of the waste remover ${ }^{a}$

${ }^{a}$ 1-Active shaft; 2-Shaft coupling; 3-Motor; 4-Passive shaft; 5-Transmission belt; 6-Passive gear; 7-Intermediate gear; 8-Active gear; 9-Belt; 10-Pump; 11-Brushing shaft; 12-Suction pipe; 13-Filter bags; 14-Body cavity; 15-Outlet pipe; 16-Impeller.

\section{Computational theory}

In order to operate the equipment, it is necessary to determine the torque on the motor shaft as a basis for selecting the engine power. A diagram of the external forces on the equipment (Figure 4) is constructed that skipping the drag force of the water, which acts on the surface of equipment, within a small velocity of the equipment. The main external forces of the equipment including: The weight of the equipment full water $(\mathrm{W})$, the thrust of the water $\left(\mathrm{F}_{A}\right)$, the thrust of the pump (Fp), the reaction of the bottom pond $(\mathrm{N})$, the force Between the outside of the belt and the bottom of the pond. From these forces, the torque can be calculated on the active axis of the belt $(\mathrm{T})$.

$$
\begin{gathered}
W=M \cdot g \\
F_{A}=\rho_{w} \cdot V_{o} \cdot g \\
F_{q}=\rho_{w} \cdot Q \cdot v \\
N=-F_{A}+W+F_{p} \\
F_{m s}=\mu \cdot N \\
T=\frac{F_{m s}}{2} r_{b}
\end{gathered}
$$

where $M$ : The mass of the equipment full water. $g$ : gravitational acceleration $\left(\mathrm{m} / \mathrm{s}^{2}\right)$.

$\rho_{w}$ : Specific gravity of water $\left(\mathrm{kg} / \mathrm{m}^{3}\right)$.

$V_{o}$ : The volume of the equipment full water $\left(\mathrm{m}^{3}\right)$.

$Q$ : Pump flow $\left(\mathrm{m}^{3} / \mathrm{s}\right)$.

$v$ : Velocity of water flow $(\mathrm{m} / \mathrm{s})$.

$\mu$ : Coefficient of friction between the outer surface of the belt and the bottom surface of the pond.

$\mathrm{r}_{b}$ : Radius of the pulley $(\mathrm{m})$.

The control system of the waste remover (Figure 5) uses two microcontrollers on the central control board and the control board communicates with each other and receives control information from the user and executes control commands for three motors.

\section{RESULTS AND DISCUSSION}

From the the initial analysis, the schematic diagram and the general diagram of the equipment's control system, the $3 \mathrm{D}$ model of the waste remover is designed by SolidWorks software (Figure 6) and the proposed operating parameters are as follows:

Speed: $15 \mathrm{~m} / \mathrm{min}$.

Total power: $500 \mathrm{~W}$.

Flow: $40 \mathrm{~m}^{3} / \mathrm{h}$.

At a speed of $15 \mathrm{~m} / \mathrm{min}$, the waste remover will operate a $1000 \mathrm{~m}^{2}(35 \times 35 \mathrm{~m})$ pond for a maximum of 2 hours and only one operator compared to two manual workers as the current practice. Electricity consumption in $2 \mathrm{~h}$ is $1 \mathrm{~kW}$ equivalent to $2.700 \mathrm{VND}$ (highest electricity price) for each pond, which saves labor costs and improves working conditions when shrimp farmers haven't to wade down to the pond to clean the bottom of the pond every day. In addition, the operator can do some value creation work while the machine is operating in automatic mode. The amount of water filtered in 2 hours is $80 \mathrm{~m}^{3}$, so the device will 


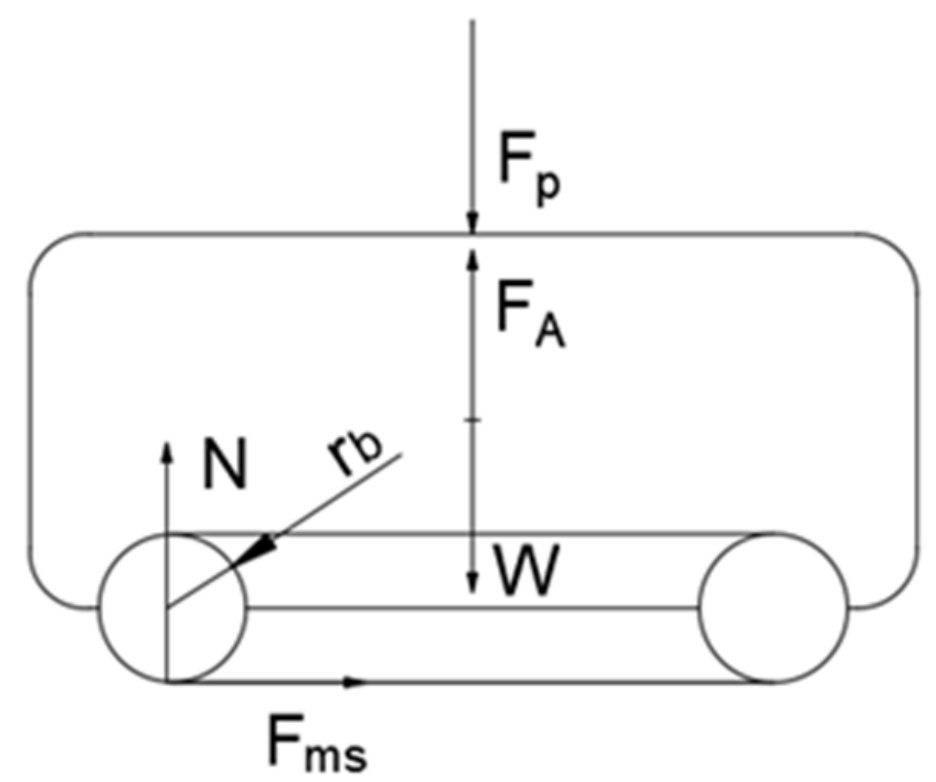

Figure 4: Diagram of external forces analysis on the equipment.

mainly absorb and filter a layer of water about $8 \mathrm{~cm}$ thick on the surface of the pond bottom, this is the area containing waste deposited should be removed from the culture environment. These results will be verified through the pilot operation of the equipment at a shrimp farm.

\section{CONCLUSION}

The waste remover was designed, manufactured and tested, met with technical requirements and available for evaluation of operating effectiveness.

\section{ABBREVIATIONS}

BOD: Biochemical Oxygen Demand COD: Chemical Oxygen Demand

TSS: Total Suspended Solids

DO: Dissolved Oxygen

FMPE: Farm Machinery and Postharvest Process Engineering

ISS: Inorganic Suspended Solids

BARI: Bangladesh Agricultural Research Institute

GPS: Global Positioning System

VND: Vietnamese Dong

\section{ONFLICT OF INTEREST}

The authors wish to confirm that there are no know conflicts of interest associated with this publication and there has been no significant financial support for this work that could have influenced its outcome.

\section{AUTHOR'S CONTRIBUTION}

All authors conceived of the study and participated in its design and coordination and helped to draft the manuscript. The authors read and approved the final manuscript.

\section{ACKNOWLEDGEMENT}

This research is supported by DCSELAB and funded by Vietnam National University Ho Chi Minh City (VNU-HCM) under grant number B2017-20b-01.

\section{REFERENCES}

1. Avnimelech $Y$, Ritvo G. Shrimp and fish pond soils: processes and management. Aquaculture. 2002;62265:1-19.

2. Delgado PC, Avnimelech Y, McNeil R, Bratvold D, Browdy CL, Sandifer P. Physical, chemical and biological characteristics of distinctive regions in paddlewheel aerated shrimp ponds. Aquaculture. 2003;217:235-248. Available from: https://doi. org/10.1016/S0044-8486(02)00231-4.

3. Boopathy, Lyles R, C. Shrimp production and biological treatment of shrimp wastewater in the United States. Aquaculture. 2008;226:101-112.

4. Boyd CE. Guidelines for aquaculture effluent management at the farm-level. Aquaculture. 2003;226:101-112. Available from: https://doi.org/10.1016/S0044-8486(03)00471-X.

5. Boopathy R, Fontenot Q, Kilgen M. Biological treatment of sludge from a recirculating aquaculture system using a sequencing batch reactor. World Aquac Soc. 2005;36. Available from: 10.1111/j.1749-7345.2005.tb00403.x.

6. Boopathy R, Bonvillain C, Fontenot Q, Kilgen M. Biological treatment of low-salinity shrimp aquaculture wastewater using sequencing batch reactor. Int Biodeterior Biodegradation. 2007;59. Available from: https://doi.org/10.1016/j.ibiod.2006.05. 003. 


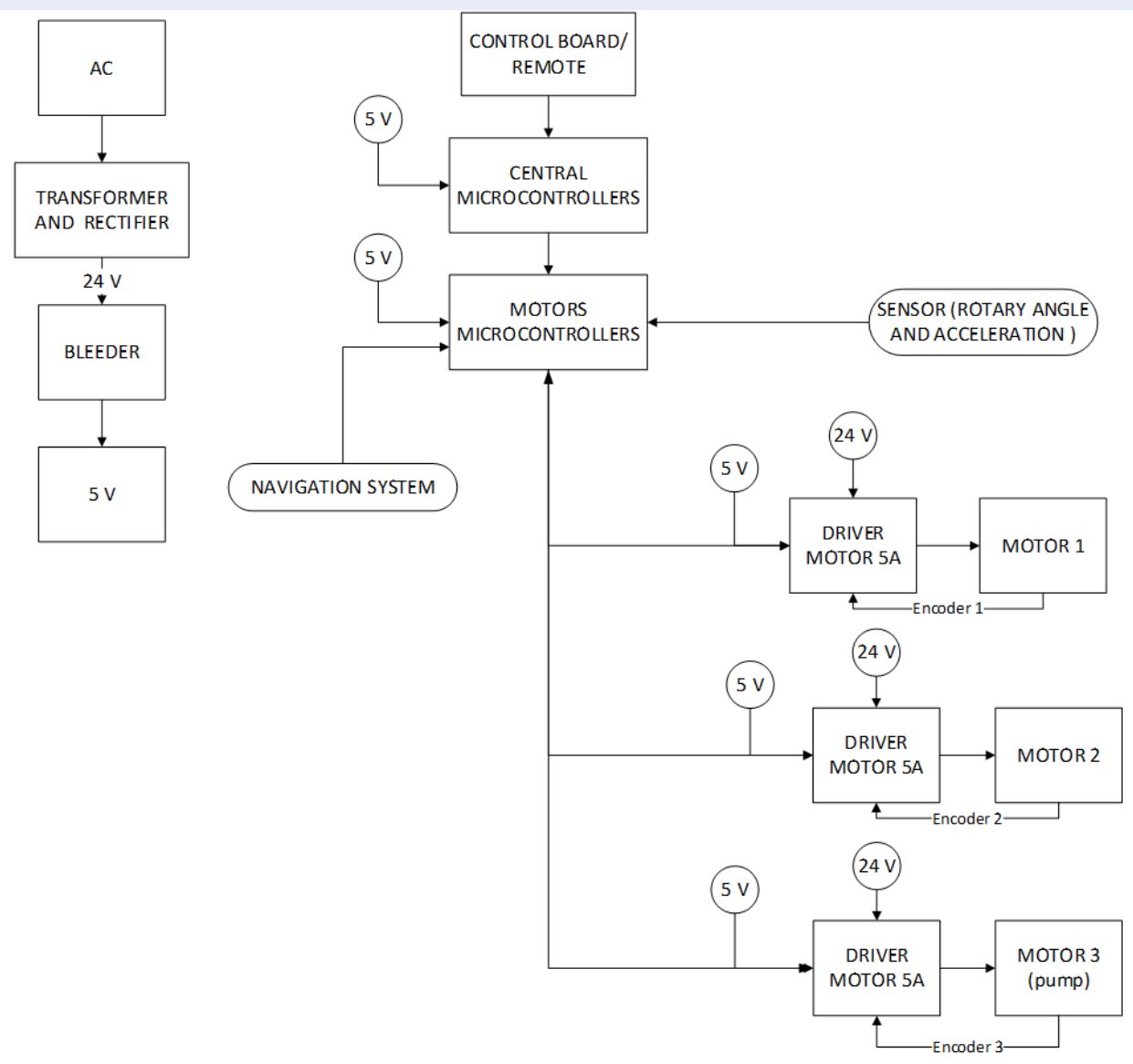

Figure 5: The control system of the waste remover.

7. Turcios AE, Papenbrock J. Sustainable treatment of aquaculture effluents-what can we learn from the past for the future? Sustainability. 2014;6:836-856. Available from: https://doi.org/10. 3390/su6020836.

8. Boyd, E C, Rajts, Francois, Firth, James. Sludge management at BAP pangasius farm cuts TAN, BOD5, TSS in discharges. Global aquaculture advocate. 2011;

9. Hossain, Ayub M, Sarker, Kumar A, Amin, Nurul M, et al. Development and performance evaluation of sludge remover for intensive aquaculture. Aquacultural Engineering. 2016;74:62-69. Available from: https://doi.org/10.1016/j.aquaeng.2016.06.001. 


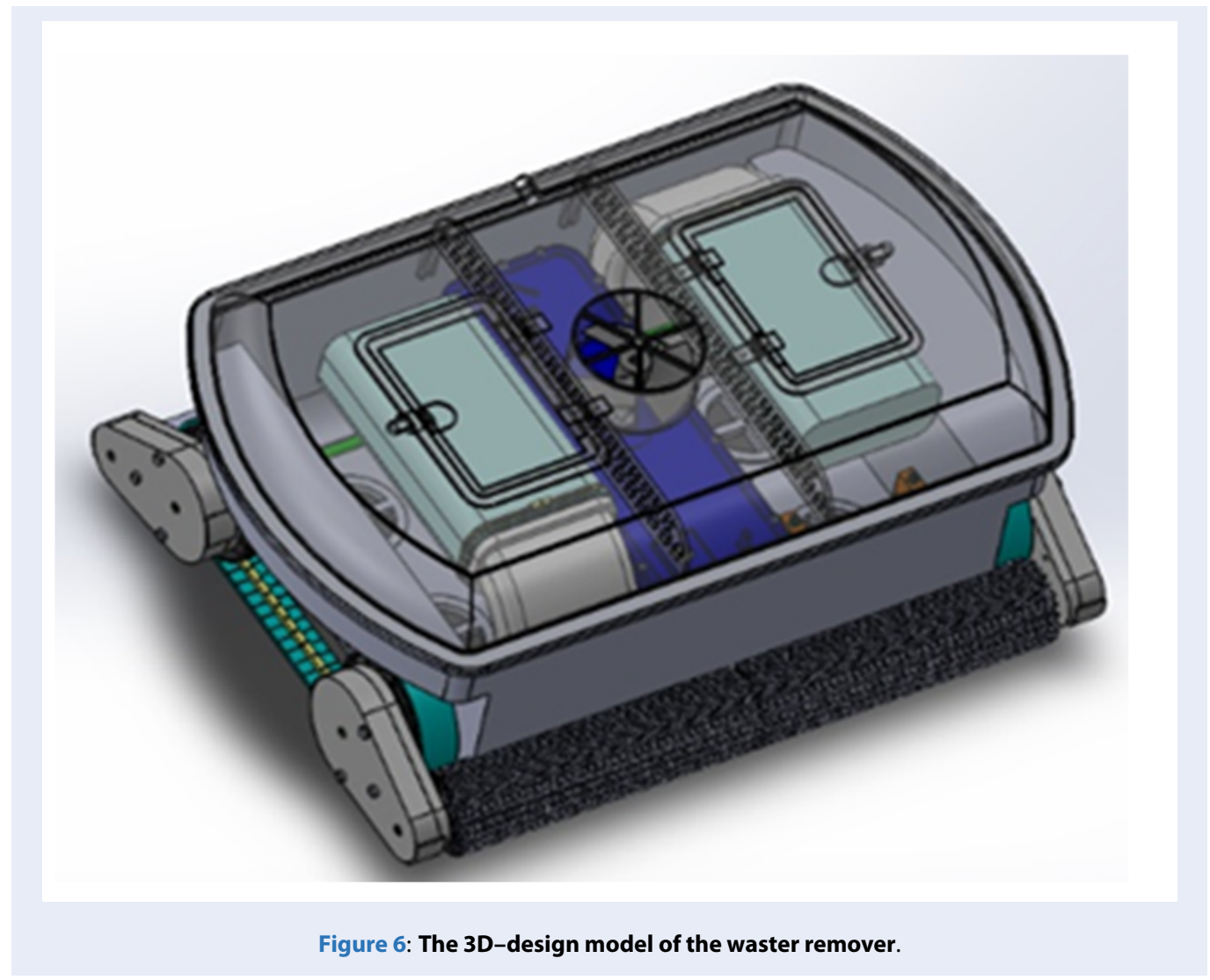




\title{
Thiết bị hút chất thải trong ao nuôi trồng thủy sản
}

\author{
Lê Thể Truyền ${ }^{1, *}$, Lê Thanh Long ${ }^{2}$
}

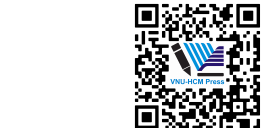

Use your smartphone to scan this QR code and download this article

\section{TÓM TẮT}

Hơn một thập kỷ qua, ngành tôm Việt Nam đã tiến bộ vượt bậc, đưa Việt Nam vào hàng ngũ các nước xuất khẩu tôm lớn nhất thế giới. Xu hướng phát triển của ngành tồm thế giới cũng như Việt Nam hiện nay đi theo hướng thâm canh và siêu thâm canh, đổi mới công nghệ nhằm nâng cao năng suất và chất lượng. Tuy nhiên, ngành nuôi tôm Việt Nam hiện nay gặp nhiều khó khăn, một trong số đó là vấn đề ô nhiểm môi trường nuôi gây tác động tiêu cực đến hiệu quả kinh tế nuôi trông. Nguyên nhân chủ yếu là do thức ăn dư thữa và chất thải từ tôm chưa được xử lý, lắng đọng dưới đáy ao và phân hủy làm giảm nồng độ oxi hòa tan, giải phóng các khí độc như NH3, H2S, tạo môi trường thuận lợi cho vi sinh vật có hại phát triển. Do đó, cần phải có biện pháp loại bỏ triệt để chất thải ra khỏi môi trường nuôi. Bài báo giới thiệu thiết kế môt thiết bi hút chất thải sử dung cho ao nuôi tôm nhằm loại bỏ chất thải ra khỏi môi trường nuôi. Để giải quyết vấn đề nêu trên, thiết bị này di chuyển trên mặt đáy ao, có khả năng tự hành hoặc được điều khiển bằng tay thông qua bộ điều khiển từ xa. Trong quá trình làm việc, thiết bị chải sạch chất thải trên bể mặt đáy ao và hút vào trong túi lọc. Thiết bị hút chất thải gồm các cụm chính: cụm di chuyển; hệ thống truyền động cho cưm di chuyển; cụm chải; hệ thống truyền động cho cụm chải; cụm hút; sử dụng nguyên lý bơm hướng trục hút chất thải theo dòng nước bằng cách làm giảm áp trong khoang thân thiết bị đông thời lọc tách chất thải bằng túi lọc, cụm khung; hệ thống điện - điêu khiển. Thiết kế này cơ bản đáp ứng các yêu cầu chức năng loại bỏ chất thải trong ao nuồi tôm, là cơ sở cho việc thiết kế các cụm chi tiết, chế tạo và thử nghiệm thiết bị sau này.

Từ khoá: Ao nuôi thủy sản, Cụm bơm, Cụm chải, Thiết bị hút chất thải
${ }^{1} P T N$ Trong diêm Điều khiển số và Kỹ thuật Hệ thống, Trường ĐH Bách khoa, ĐHQG-HCM; Việt Nam

${ }^{2}$ Khoa Cơ khí, Trường Đại học Bách khoa, ĐHQG-HCM, Việt Nam

Liên hệ

Lê Thể Truyền, PTN Trọng điểm Điều khiển số và Kỹ thuật Hệ thống, Trường ĐH Bách khoa, ĐHQG-HCM; Việt Nam

Email: truyenlt@hcmut.edu.vn

Lịch sử

- Ngày nhận: 15/10/2018

- Ngày chấp nhận: 15/12/2018

- Ngày đăng: 31/12/2019

DOI : 10.32508/stdjet.v3iSI1.729

\section{Check for updates}

\section{Bản quyền}

๑ ĐHQG Tp.HCM. Đây là bài báo công bố mở được phát hành theo các điều khoản của the Creative Commons Attribution 4.0 International license.

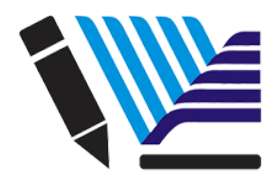

VNU-HCM Press
Trích dẫn bài báo này: Truyền $L T$, Long $L T$. Thiết bị hút chất thải trong ao nuôi trồng thủy sản. Sci. Tech. Dev. J. - Eng. Tech.; 2(SI1):SI112-SI119. 